\title{
Covid-19 Outbreak in Sabah: A Prelimiary Survey on its Effects on Hotel Industry \& Some Key Concerns During Pre- Movement Control Order Period
}

Rafiq Idris, Kasim Mansur, Rizal Zamani Idris, Mori Kogid

To Link this Article: http://dx.doi.org/10.6007/IJARBSS/v10-i11/8137 DOI:10.6007/IJARBSS/v10-i11/8137

Received: 09 September 2020, Revised: 12 October 2020, Accepted: 14 November 2020

Published Online: 30 November 2020

In-Text Citation: (Idris et al., 2020)

To Cite this Article: Idris, R., Mansur, K., Idris, R. Z., \& Kogid, M. (2020). Covid-19 Outbreak in Sabah: A Prelimiary Survey on its Effects on Hotel Industry \& Some Key Concerns During Pre-Movement Control Order Period. International Journal of Academic Research in Business and Social Sciences, 10(11), 771-778.

Copyright: (c) 2020 The Author(s)

Published by Human Resource Management Academic Research Society (www.hrmars.com) This article is published under the Creative Commons Attribution (CC BY 4.0) license. Anyone may reproduce, distribute, translate and create derivative works of this article (for both commercial and non-commercial purposes), subject to full attribution to the original publication and authors. The full terms of this license may be seen at: http://creativecommons.org/licences/by/4.0/legalcode

Vol. 10, No. 11, 2020, Pg. 771 - 778

Full Terms \& Conditions of access and use can be found at http://hrmars.com/index.php/pages/detail/publication-ethics 


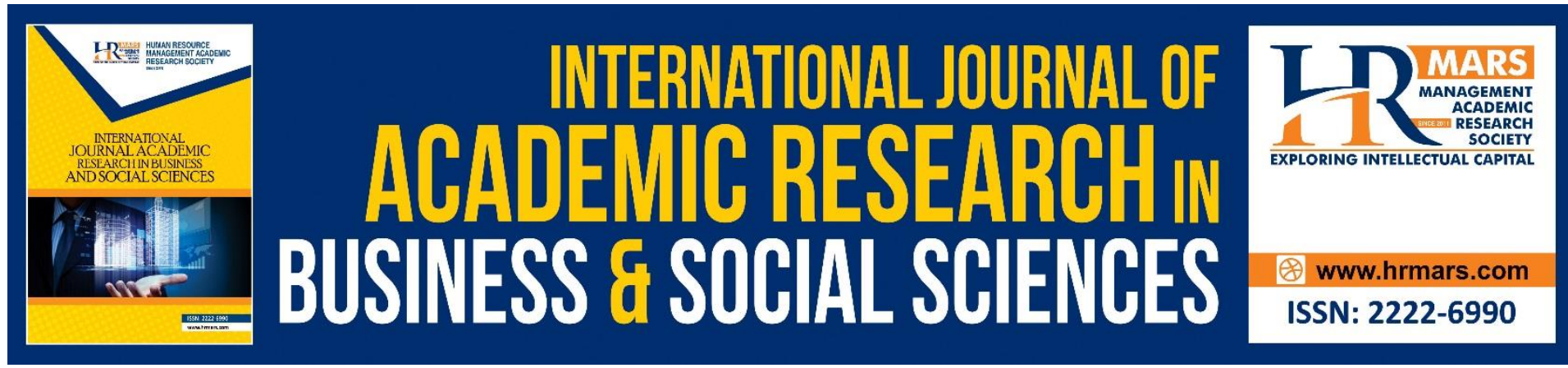

\title{
Covid-19 Outbreak in Sabah: A Prelimiary Survey on its Effects on Hotel Industry \& Some Key Concerns During Pre-Movement Control Order Period
}

\author{
Rafiq Idris ${ }^{1}$, Kasim Mansur ${ }^{1}$, Rizal Zamani Idris², Mori Kogid ${ }^{1}$ \\ ${ }^{1}$ Faculty of Business, Economics and Accountancy, Universiti Malaysia Sabah, Malaysia \\ ${ }^{2}$ Faculty of Social Sciences and Humanities, Universiti Malaysia Sabah, Malaysia
}

Email: rafiq8idris@gmail.com

\begin{abstract}
Malaysia was ranked the first position in the Global Muslim Travel Index 2019 (Global Muslim Travel Index, 2019). Besides, the Travel and Tourism Competitiveness Report 2019 ranked Malaysia at $29^{\text {th }}$ out of 140 countries overall (Travel and Tourism Competitiveness Report, 2019). In the same report, from Travel and Tourism Policy and Enabling Conditions' perspective, Malaysia was ranked at the $11^{\text {th }}$ position (Travel and Tourism Competitiveness Report, 2019). Government of Malaysia has, among others, announced year 2020 as the Visit Malaysia Year to attract more tourists. The first month of the year had showed promising numbers of tourists' arrivals. However, towards the end of January 2020, CoVID-19 outbreak presents the tourism industry with a major challenge. Following the outbreak, some countries have banned the arrival of tourists from certain countries. Accordingly, this has somehow affected the hotel industry. Based on feedbacks from hotel employees, this paper examines the preliminary effects on hotel industry in Sabah, Malaysia.
\end{abstract}

Keyword: Sabah, Malaysia, COVID-19, Tourism, Economy, Impact.

\section{Introduction}

Malaysia was ranked the first position in the Global Muslim Travel Index 2019 (Global Muslim Travel Index, 2019). The Travel and Tourism Competitiveness Report 2019 ranked Malaysia at 29th out of 140 countries overall (Travel and Tourism Competitiveness Report, 2019). In the same report, from Travel and Tourism Policy and Enabling Conditions' perspective, Malaysia was ranked at the $11^{\text {th }}$ position (Travel and Tourism Competitiveness Report, 2019). The country was also ranked $22^{\text {nd }}$ in the world by tourist arrivals in 2018 (World Bank, 2019).

The year 2020 has been chosen as Visit Malaysia Year to promote Malaysia's tourism. The first month of the year had shown interesting trend based on the number of tourists' arrivals. However, towards the end of January 2020, the Corona virus (CoVID-19) outbreak presents the tourism sector with a major challenge. In this regard, the World Tourism Organization (UNWTO) has strengthened its collaboration with the World Health Organization (WHO) with the former calling for solid international leadership and for tourism 
to be included as a priority in future recovery efforts since it is currently one of the most seriously affected sectors.

Since the outbreak of Covid-19, some countries have shut their borders and banned the arrival of tourists from certain countries. Apparently, this has severely affected many economic sectors especially tourism. For the state of Sabah, Malaysia, the state government has banned tourists from certain countries from visiting the state, while some big events have been postponed. Being an open economy where international trade (Idris, 2016) and tourism sector is one of the important contributors to the economy, CoVID-19 somehow affect the sector performance. The objectives of the study are as follows:

- To examine the preliminary effects of CoVID-19 on hotel industry during premovement control order period based on the feedbacks from hotel employees in Sabah.

- To study the preliminary concern of hotel employees during pre-movement control order period

\section{Literature Review}

Considering the outbreak of Covid-19 is relatively new, there appears to be limited studies on this subject though some related studies or report can be found such as ADB (2020), KPMG (2020), International Labor Organization (2020) and Congressional Research Service (2020). By and large, they are not as rigorous as studies on other diseases and their impacts on economy.

\section{Methodology}

This research conducted a survey involving 100 workers of hotels in Kota Kinabalu, Tawau and Sandakan, Sabah, Malaysia to obtain feedbacks on their views related to the effects of CoVID19 outbreak on hotel industry up to the end of February 2020.

\section{Results}

Figure 1, 2, 3, 4 and 5 show some of the key findings of the study. Figure 1 depicts the input given by respondents with regard to the degree of effects of Covid-19 on the hotel's business. The chart shows that $84 \%$ of the respondents indicated that their hotels businesses had suffered a major effect from Covid-19 outbreak. $11 \%$ believed that it was a moderate effect while the other $5 \%$ expressed that it was just causing a minor effect (as at the end of February 2020). In general, majority of the respondents felt Covid-19 caused a major effect.

Figure 2 shows which month of the year is the worst in terms of the effect of Covid19. All the respondents expressed that February 2020 was the worst as opposed to the month of January 2020. This can be attributed to the banning of tourist's entry from certain countries. 


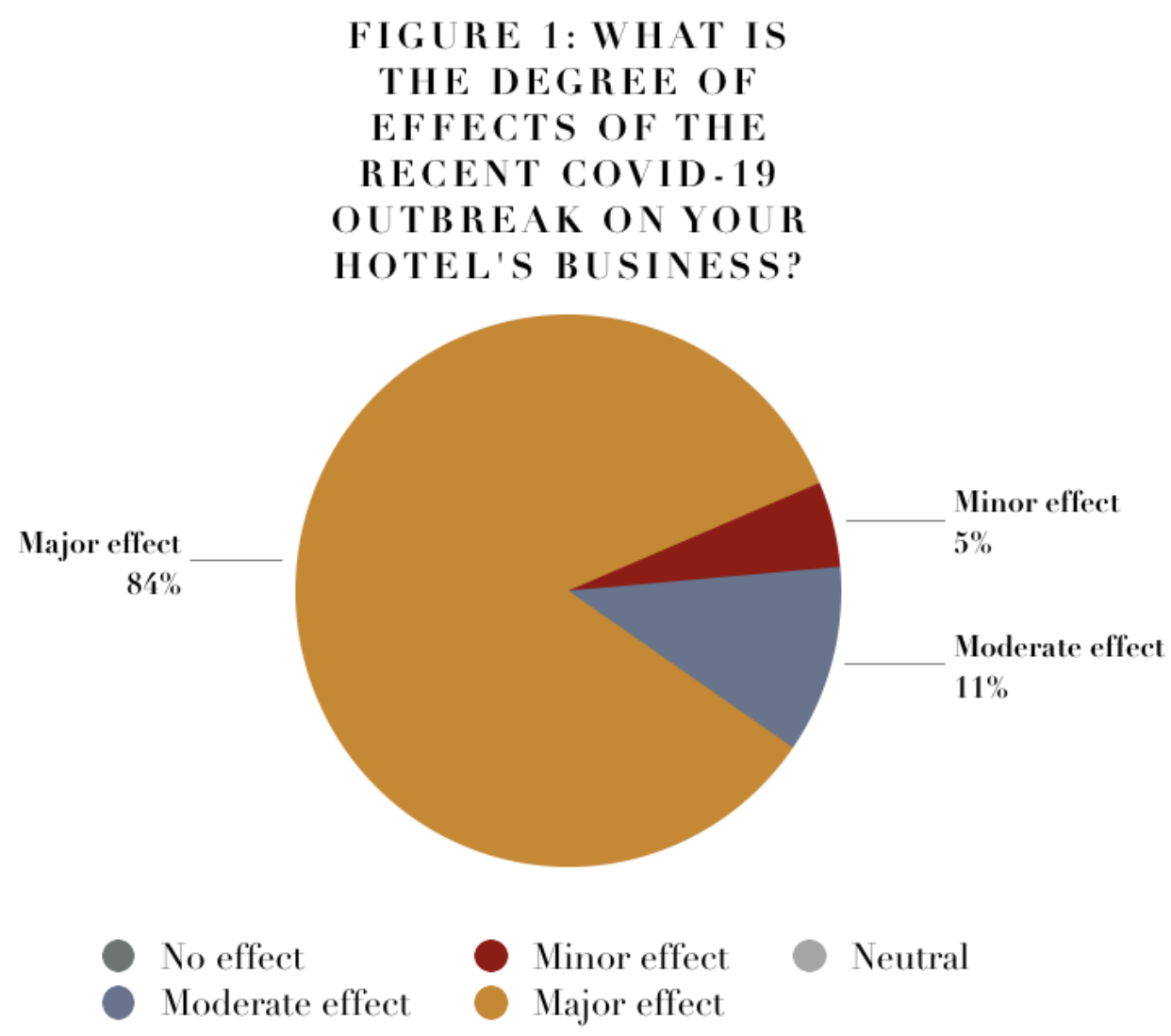

FIGURE 2: IF THE

EFFECT IS FELT,

WHICH MONTH IS

THE WORST?

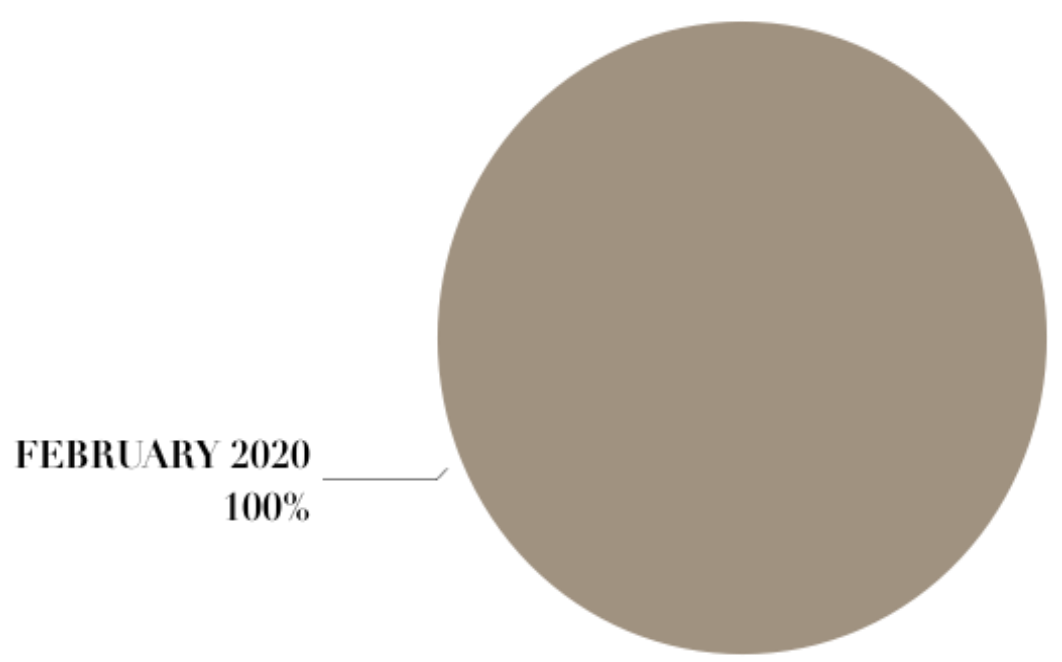

JANUARY $2020 \bigcirc$ FEBRUARY 2020 
FIGURE 3: WHICH ASPECT

OF YOUR HOTEI'S

BUS INESS IS BEING

AFFECTED THE MOST?

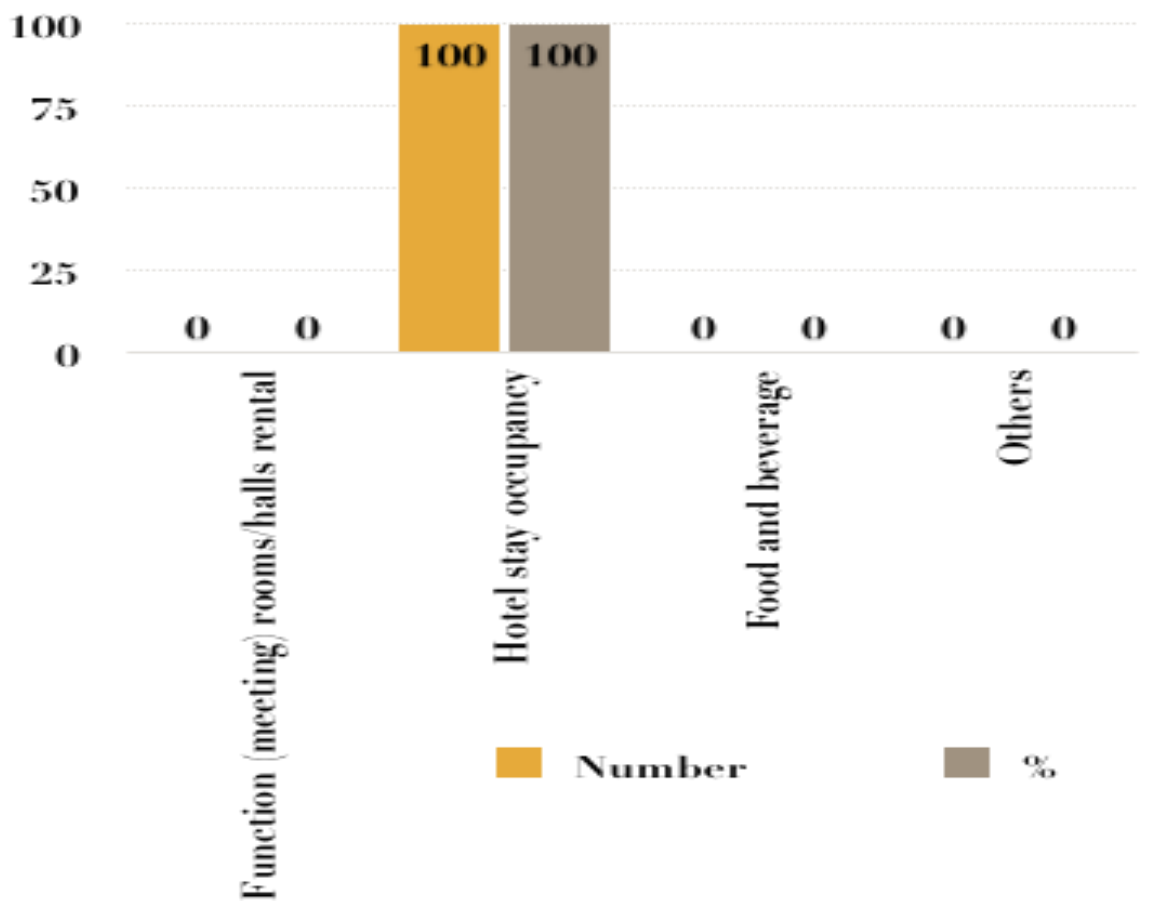

Figure 3 shows the view of respondents with regard to the services that are most affected at the end of February 2020. The respondents indicated that hotel occupancy was affected the most. Other services that were not as badly affected as hotel stay occupancy were function (meeting) rooms/halls rental and food and beverage. 


\section{FIGURE 4: WHAT IS THE AVERAGE \\ RANGE OF OCCUPANCY RATE AT \\ YOUR HOTEL IN JANUARY 2020 \\ BEFORE THE RESTRICTION OF \\ ENTRY OF TOURISTS FROM \\ CERTAIN COUNTRY IN JANUARY \\ 2020 IN PERCENTAGE OF RESPONDENTS?}

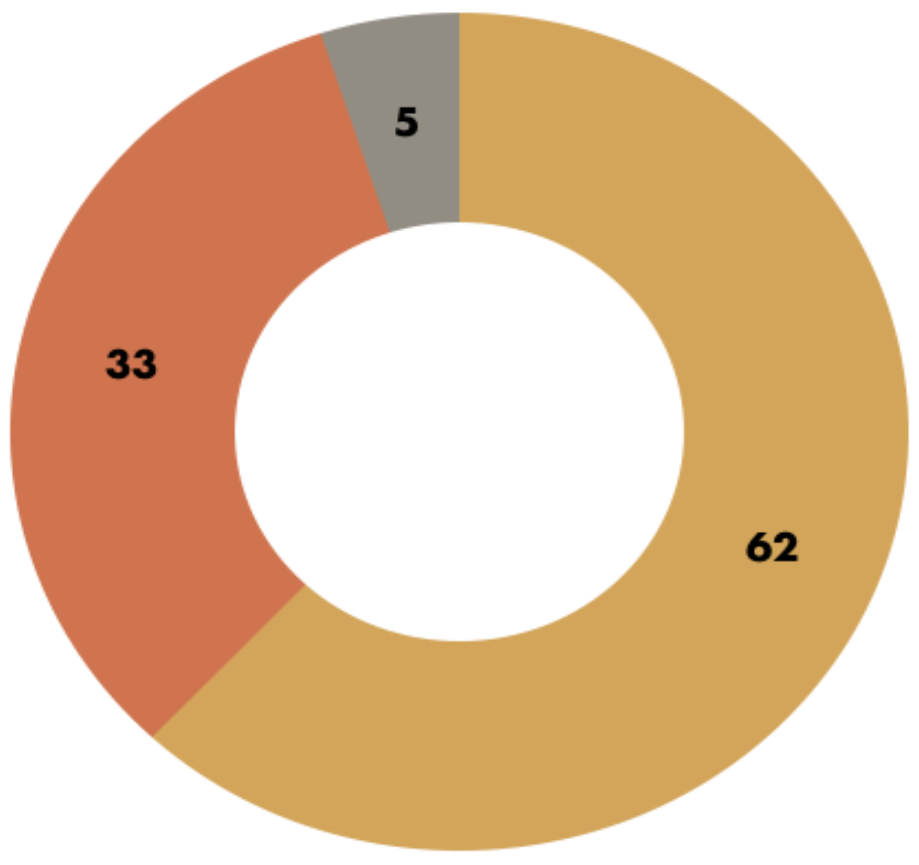

$70-100 \%$ $50-69 \%$ $30-49 \%$

$1-29 \%$

For the month of January 2020,62\% of respondents expressed that the occupancy rate at the hotel that they were working were in the range of $70-100 \% .33 \%$ indicated the range of $50-69 \%$ while $5 \%$ indicated the range of $30-49 \%$ (see Figure 4).

On the occupancy rate for the month of February 2020, which was during a period where tourists from certain countries were restricted to enter Malaysia due to Covid-19, 78\% of respondents expressed that it was in the range of 1-29\% especially during final week of the month (see figure 5). Table 1 highlights the summary of some preliminary concerns of the hotel workers with regard to the effects of Covid-19. 


\section{FIGURE 5: WHAT IS THE \\ OCCUPANCY RATE AT \\ YOUR HOTEL IN THE \\ FINAL WEEK OF \\ FEBRUARY 2020?}

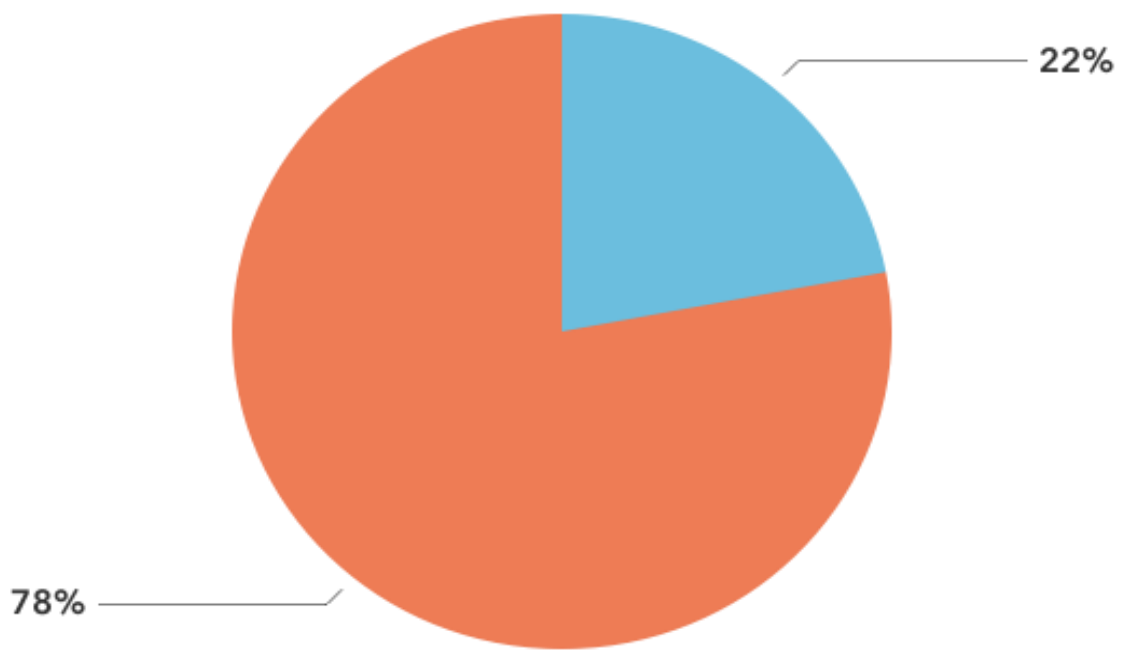

\section{$70-100 \%-50-69 \% \bigcirc 30-49 \% \bigcirc 1-29 \%$}

Table 1: Summary preliminary concern of selected stakeholders

\begin{tabular}{|l|l|}
\hline CONCERN & RECOMMENDATIONS \\
\hline Salary cut & $\begin{array}{l}\text { Government intervention so that it will not } \\
\text { happen or can be minimized } \\
\text { (subsidy/government aid through stimulus } \\
\text { packages) }\end{array}$ \\
\hline Contract staff might lose their job & $\begin{array}{l}\text { Government intervention so that it will not } \\
\text { happen or can be minimized (through } \\
\text { assistance to employers/government aid } \\
\text { through stimulus package) }\end{array}$ \\
\hline Permanent staff will lose their job & $\begin{array}{l}\text { Government intervention so that it will not } \\
\text { happen or can be minimized (by having } \\
\text { government aid through stimulus packages) }\end{array}$ \\
\hline Loss of income & $\begin{array}{l}\text { Government intervention so that loss can } \\
\text { be minimized. Cash aid for B-40 group can } \\
\text { be considered }\end{array}$ \\
\hline $\begin{array}{l}\text { Significant reduction for tourists visits in } \\
\text { the next few months especially from } \\
\text { foreign country }\end{array}$ & $\begin{array}{l}\text { Government intervention so that it will not } \\
\text { happen or can be minimized (through } \\
\text { stimulus packages or incentive to } \\
\text { encourage domestic tourism) }\end{array}$ \\
\hline $\begin{array}{l}\text { There are hotels that might not be able to } \\
\text { sustain if the outbreak continues for } \\
\text { months }\end{array}$ & $\begin{array}{l}\text { Government intervention so that it will not } \\
\text { happen or can be minimized (through } \\
\text { stimulus packages or incentive to } \\
\text { encourage domestic tourism) }\end{array}$ \\
\hline
\end{tabular}




\section{Conclusion}

The Covid-19 outbreak has caused many businesses to suffer substantial loss of income. For the case of Sabah, Malaysia, tourism sector especially the hotel industry is one of the sectors that took a direct impact i.e. slowdown in business activities especially in the final week for the month of February 2020. This can be attributed to the restriction of entry of tourists from certain country. Things worsened when many Malaysians started to take precautionary steps to protect themselves by delaying or cancelling domestic vacations, trips and visits. The significant drop of sales resulted in less than $50 \%$ occupancy rate by end of February 2020 for many hotels whereby it used to be over $50 \%$ in the previous months. Apparently, rooms occupancy was the one that had dropped the most.

Studies on the impact of diseases on economy, specifically for tourism sector is limited at least for the case of Sabah, Malaysia. The current CoVID-19 pandemic which is a new thing have adverse effects on Malaysia's tourism sector. The findings of this study fill in the gap in the literature by adding new research to the body of knowledge and provide beneficial information for various stakeholders including policy makers. The findings itself are significant for body of knowledge by highlighting the real economic effects of CoVID-19 on economy of Sabah, at least from hotel industry perspective. The finding of the study also confirms the findings of some past studies with regard to the impact of CoVID-19 and human movement restriction on economic activities.

\section{Acknowledgement}

This research is a part of several research conducted on the impact of CoVID-19 on economy funded by UMS research grant (SDK0250-2020).

\section{References}

Asian Development Bank. (2020). The Economic Impact of the COVID-19 Outbreak on Developing Asia. https://www.adb.org/sites/default/files/publication/571536/adbbrief-128-economic-impact-covid19-developing-asia.pdf

Congressional Research Service. (2020). Global Economic Effects of COVID-19. https://fas.org/sgp/crs/row/R46270.pdf

International Labor Organization. (2020). COVID-19 and the world of work: Impact and policy responses.https://www.ilo.org/wcmsp5/groups/public/---dgreports/--dcomm/documents/briefingnote/wcms_738753.pdf

Idris, R. (2015). Sabah in 1962 and 2011: A Snapshot of Its Foreign Trade and Comparative Advantage. Asia Pacific Journal of Research. 1(38), 192-199 